\title{
Is neck circumference measurement an indicator for abdominal obesity? A pilot study on Turkish Adults
}

\author{
*Mendane Saka, Perim Türker, Aydan Ercan, Gül Kızltan, Murat Baş
}

Başkent University, Health Science Faculty, Department of Nutrition and Dietetics, Ankara, Turkey

\begin{abstract}
Background: Neck circumference (NC) measurement is one of the simple screening measurements which can be used as an index of upper body fat distribution to identify obesity.

Objectives: The aim of this study was to determine the relationship between neck circumferences and obesity.

Methods:A total 411 volunteer adults participated in this study (174 men, 237 women). A questionnaire which consisted of anthropometric measurements and demographic features was used. Patients with NC $\geq 37 \mathrm{~cm}$ for men and $\geq 34 \mathrm{~cm}$ for women require evaluation of overweight status.

Results: The percentages of the men and women with BMI $\geq 25 \mathrm{~kg} / \mathrm{m}^{2}$ were $55.2 \%$ and $27.0 \%$ respectively and with high neck circumferences were $85.1 \%$ and $38.8 \%$, respectively. The percentages of the men and women with high waist circumference were $31.6 \%$ and $79.3 \%$, respectively. In both gender there were positive significant correlations between neck circumference, body weight (men, $r=0.576$; women, $r=0.702$; $\mathrm{p}=0.000$ ), waist circumferences (men, $r=0.593$; women $r=0.667 ; p=0.000$ ), hip circumferences (men, $r=0.568$; women, $r=0.617$; $p=0.000$ ) and BMI (men, $r=0.587$; women, $r=0.688$; $p=0.000)$.

Conclusions: This study indicates that NC was associated with body weight, BMI, waist and hip circumferences and waist/ hip ratio for men and women. A significant association was found between NC and conventional overweight and obesity indexes. NC was associated with waist/hip ratio for men and women.
\end{abstract}

Key words: Neck circumference, obesity.

DOI: http://dx.doi.org/10.4314/ahs.v14i3.11

\section{Introduction}

Obesity is associated with several risk factors for later cardiovascular and metabolic disturbances. These disorders require close monitoring to prevent long-term effects. Obesity, particularly when it occurs in upper part of body, is a major health problem. ${ }^{[1-3]}$ Overweight is defined as a body mass index (BMI) between 25.0 and $29.9 \mathrm{~kg} / \mathrm{m}^{2}$ and obesity is defined as a BMI of $30.0 \mathrm{~kg} /$ $\mathrm{m}^{2}$ or higher. There are numerous methods of assessing overweight and obesity. Some techniques are applicable, such as measurement of weight, height, abdominal and hip circumferences, waist/hip ratio and BMI. ${ }^{[5]}$ Body mass index (BMI) is the most used marker of both adult and childhood obesity, but not a good indicator of body fat. ${ }^{[4]}$ Other procedures, such as ultrasound,

\section{* Corresponding Author}

Başkent University, Health Science Faculty, Department of Nutrition and Dietetics, Baglica Kampusu, Eskișehir Yolu, 20.km Etimesgut, Ankara/ TURKEY

Phone: +90 3122461609

E-mail:saka@baskent.edu.tr computed tomography, and magnetic resonance imaging are expensive and are primarily used for research purposes. ${ }^{[5]}$

In the assessment of central obesity, various techniques are used: waist circumference, waist/hip ratio, mid-upper arm circumference, subscapular/ triceps ratio and neck circumference. ${ }^{[1]}$ The neck circumference is more accurate than BMI because of the strong correlation between high neck circumference measurements and central adiposity (fat around the abdomen). The technique was also more convenient than waist circumference. ${ }^{[4]}$ Neck circumference (NC) measurement is a simple screening measure, as an index of upper body fat distribution that can be used to identify overweight and obese people. ${ }^{[5,6]} \mathrm{NC}$,also a time saving anthropometric measurement, is identified as an index of central obesity. Framingam heart study demonstrated that $\mathrm{NC}$ was independently associated with visceral adipose and BMI.NC plays an independent contribution to predicting the metabolic abnormalities beyond the classical anthropometric indices of BMI, WC and waist to hip ratio(WHpR) and may be used as an optimal screening other obesity related chronic diseases. ${ }^{[7,8]}$ 
Various methods are available to measure fat mass, such as magnetic resonance imaging (MRI) and computed tomography (CT), although they are unsuitable for studies requiring large populations. Dual energy absorptiometry (DXA) scanning is an accurate alternative measure of fat mass that is well suited for studies in clinical settings due to its relatively lower associated costs, training expertise, and radiation exposure. it remains unknown whether DXAmeasured regional fat can predict better than traditional anthropometric measures. ${ }^{[9]}$

Neck circumference is significantly associated with cardiovascular disease (CVD) risk factors such as elevated insulin, high-density lipoprotein (HDL) cholesterol, and homeostasis model assessment (HOMA-IR). The neck circumference is positively associated with insulin and HOMA-IR, and negatively associated with HDL cholesterol, and fasting glucose to insulin ratio(FGIR). All anthropometric indices are positively associated with systolic blood pressure and triglycerides, while neck circumference, WC, HC, and WHpR are associated with diastolic blood pressure. ${ }^{[10]}$

Therefore, the objective of this study was to determine the relationship between neck circumferences and obesity.

\section{Methods \\ Subjects}

A total of 411 volunteer adults (age between 20-60 years) participated in this study (174 men, 237 women).

\section{Questionnaire}

Aquestionnaire, which consisted of demographic features, was administered by face to face interview.

\section{Anthropometric Measurements}

Body weight, height, neck circumference (NC), waist and hip circumferences were measured and Body Mass Index was calculated $\left[\left(\mathrm{BMI}=\right.\right.$ weight $(\mathrm{kg}) /$ height $\left.(\mathrm{m})^{2}\right]$. BMI was categorized according to WHO classifications. The patients were grouped into four categories; underweight, normal-weight, overweight and obese in accordance with the cut-off points of $<18.5 \mathrm{~kg} / \mathrm{m}^{2}$, 18.5 to $24.9 \mathrm{~kg} / \mathrm{m}^{2}, 25.0$ to $29.9 \mathrm{~kg} / \mathrm{m}^{2}$ and $>30 \mathrm{~kg} / \mathrm{m}^{2}$ respectively ${ }^{[11]}$. Circumferences were measured using an inelastic tape with one millimetre precision. Waist circumference was measured at the midpoint between the inferior costal margin and the upper iliac crest. The hip circumference was obtained at the level of the femoral trochanters and the neck circumference was measured below the cricoid cartilage, and afterwards, at the level of the mid cervical spine. ${ }^{[12]} \mathrm{WHO}$ waist circumferences $(>102 \mathrm{~cm}$ for men, $>88 \mathrm{~cm}$ for women) and waist/hip ratio cut-off points $(>1$ for men, $>0.85$ for women) were used. ${ }^{[13]}$ Patients with $\mathrm{NC} \geq 37 \mathrm{~cm}$ for men and $\geq 34 \mathrm{~cm}$ for women require evaluation of overweight status. ${ }^{[5]}$

\section{Data analysis}

The results were expressed as the mean \pm , standard deviation $( \pm \mathrm{SD})$ and percentages. Correlation test was used to compare the percentage of risk factors among men and women. Multi variate regression models were estimated to determine the independent relationship of each variable with the outcome variable (NC). The statistical analyses were performed with SPSS version 13.0 for Windows. Differences were considered significant with a probability value of $\mathrm{p}<0.05$.

\section{Results}

The mean age of the participants was $32.4 \pm 12.03$ years. The $59.5 \%$ of them were women, $40.5 \%$ of them were men. The mean BMI was $22.9 \pm 4.34 \mathrm{~kg} / \mathrm{m}^{2}$ for women, $25.7 \pm 3.92 \mathrm{~kg} / \mathrm{m}^{2}$ for men. The $55.2 \%$ of the men and $27.0 \%$ of the women were overweight and obese (BMI $\geq 25 \mathrm{~kg} / \mathrm{m}^{2}$ ). The mean waist and hip circumferences of the women and the men were $77.7 \pm 12.82 \mathrm{~cm}$, $95.8 \pm 12.14 \mathrm{~cm}$ and $99.2 \pm 10.17 \mathrm{~cm}, 105.3 \pm 9.71 \mathrm{~cm}$, respectively. The waist/hip ratio was $0.78 \pm 0.08$ in women, $0.91 \pm 0.07$ in men. The percentages of the men and women with high waist circumference were $31.6 \%$ and $79.3 \%$, respectively. The mean NC of men and women were $40.27 \pm 3.41 \mathrm{~cm}, 33.43 \pm 3.17 \mathrm{~cm}$, respectively. The $85.1 \%$ of men and $38.8 \%$ of women's neck circumference measurements were higher than the standards. 
Table1. Anthropometric measurements of participants

\begin{tabular}{|c|c|c|c|c|}
\hline \multirow[t]{2}{*}{$\begin{array}{l}\text { Anthropometric } \\
\text { measurements }\end{array}$} & \multicolumn{2}{|c|}{$\begin{array}{c}\text { Men } \\
(n=174)\end{array}$} & \multicolumn{2}{|c|}{ Women $(n=237)$} \\
\hline & $\mathbf{X}$ & SS & $\mathbf{X}$ & SS \\
\hline Weight, kg & 80.7 & 14.23 & 61.2 & 11.19 \\
\hline Height, $\mathrm{cm}$ & 176.9 & 6.89 & 163.3 & 6.37 \\
\hline BMI, $\mathrm{kg} / \mathrm{m}^{2}$ & 25.7 & 3.89 & 22.9 & 4.34 \\
\hline Waist circumference, $\mathrm{cm}$ & 95.8 & 12.14 & 77.7 & 12.82 \\
\hline $\begin{array}{l}\text { Hip circumference, } \mathrm{cm} \\
\text { Neck circumference, } \mathrm{cm}\end{array}$ & $\begin{array}{l}105.3 \\
40.27\end{array}$ & $\begin{array}{l}9.71 \\
3.41\end{array}$ & $\begin{array}{c}99.2 \\
33.43\end{array}$ & $\begin{array}{l}10.17 \\
3.17\end{array}$ \\
\hline Waist/hip ratio & $\begin{array}{c}0.91 \\
\mathbf{n}\end{array}$ & $\begin{array}{c}0.07 \\
\%\end{array}$ & $\begin{array}{c}0.78 \\
\mathbf{n}\end{array}$ & $\begin{array}{l}0.08 \\
\%\end{array}$ \\
\hline BMI, $\geq 25 \mathrm{~kg} / \mathrm{m}^{2}$ & 96 & 55.2 & 64 & 27 \\
\hline Waist circumference, $\mathrm{cm} \geq 102$ male, $\geq 88$ female & 55 & 31.6 & 188 & 79.3 \\
\hline Neck circumference, $\mathrm{cm} \geq 37$ male, $\geq 34$ female & 148 & 85.1 & 92 & 38.8 \\
\hline
\end{tabular}

In both gender, neck circumference correlated positively with body weight (men, $r=0.576$; women, $r=0.702$; each $\mathrm{p}=0.000$ ), waist circumferences (men, $r=0.593$; women $r=0.667$; each $p=0.000$ ), hip circumferences (men, $r=0.568$; women, $r=0.617$; each $p=0.000$ ), waist-hip ratio( men, $r=0.273$; women, $r=0.450$; each $\mathrm{p}=0.000$ ) and BMI (men, $r=0.587$; women, $r=0.688$; each $p=0.000$ ).

In the regression analysis, we examined the relative importance of $\mathrm{NC}$ with the BMI, body weight, waist and hip circumferences. The multiple regression models showed a significant relationship between NC and BMI, body weight, waist and hip circumferences. $\mathrm{R}^{2}$ statistics for the models were 0.425 in men and 0.535 in women.

According to the kappa statistics, we determined the fair agreement between $\operatorname{BMI}(x=0.306)(\mathrm{p}<0.000)$ , slight agreement waist circumferences $(x=0.14)$ $(p<0.000)$ and poor agreement waist to hip ratio $(x$ $=0.004)(\mathrm{p}=0.825)$ and $\mathrm{NC}$ in men. In the kappa statistics, we found the moderate agreement between $\operatorname{BMI}(x=0.511) \quad(\mathrm{p}<0.000)$, waist $\operatorname{circumferences}(x$ $=0.524)(\mathrm{p}<0.000)$ and examined fair agreement waist 
Table 2. The correlation between anthropometric measurements and neck circumference of participants to hip ratio $(x=0.341)(\mathrm{p}<0.000) \mathrm{NC}$ in women.

\begin{tabular}{|c|c|c|c|c|}
\hline \multirow{3}{*}{$\begin{array}{l}\text { Anthropometric } \\
\text { measurements }\end{array}$} & \multicolumn{4}{|c|}{ Neck circumference $(\mathrm{cm})$} \\
\hline & \multicolumn{2}{|c|}{ Men (n=174) } & \multicolumn{2}{|c|}{ Women $(n=237)$} \\
\hline & $\mathbf{r}$ & $\mathrm{p}$ & $\mathbf{r}$ & $\mathrm{p}$ \\
\hline Weight, kg & 0.576 & 0.000 & 0.702 & 0.000 \\
\hline BMI, $\mathrm{kg} / \mathrm{m}^{2}$ & 0.587 & 0.000 & 0.688 & 0.000 \\
\hline Waist circumference, $\mathrm{cm}$ & 0.593 & 0.000 & 0.667 & 0.000 \\
\hline Hip circumference, $\mathrm{cm}$ & 0.568 & 0.000 & 0.617 & 0.000 \\
\hline Waist/hip ratio & 0.273 & 0.000 & 0.450 & 0.000 \\
\hline
\end{tabular}

\section{Discussion}

Overweight and obesity are defined as excessive body fat accumulation that it may have an adverse effect on health, leading to reduced life expectancy and increased health problems. WHO defines people as overweight if their BMI is between 25 and $30 \mathrm{~kg} / \mathrm{m}^{2}$, and obese when it is greater than $30 \mathrm{~kg} / \mathrm{m}^{2}$. Over weight and obesity are major risk factors for a number of chronic diseases, including diabetes, cardiovascular diseases and cancer. ${ }^{[14,15,16,17]}$

Before the 20th century, obesity was rare; ${ }^{[18]}$ in 1997 the WHO formally recognized obesity as a global epidemic. ${ }^{[19]}$ According to WHO report $65 \%$ of the world's population live in countries where overweight and obesity kills more people than underweight. ${ }^{[20]}$

The prevalence of obesity in Europe is estimated to be $10 \%$ to $20 \%$ of adult men and $15 \%$ to $25 \%$ of adult women. ${ }^{[21]}$ In the United States, the prevalence of overweight and obesity was $59.4 \%$ for men, $50.7 \%$ for women, between 1988 and 1994. ${ }^{[22]}$ In Turkey, according to Turkish Adult Risk Factor Study (TEKHARF), the prevalence of overweight and obesity were $44.2 \%$ for women, $25.2 \%$ for men. ${ }^{[23]}$

There are numerous methods of assessing overweight and obesity. ${ }^{[5]}$ The most common criteria to determine overweight and obesity is BMI. However, to define fat distribution, BMI is a less suitable to assess body fat distribution. In the assessment of central obesity, various techniques are used: waist circumference, waist/ hip ratio, and neck circumference. Waist circumference was defined as an index to reveal central obesity and could be used identify overweight and obesity. ${ }^{[1]}$

In this study, the mean BMI was $22.9 \pm 4.34 \mathrm{~kg} /$ $\mathrm{m}^{2}$ for women $25.7 \pm 3.92 \mathrm{~kg} / \mathrm{m}^{2}$ for men. The $55.2 \%$ of the men and $27.0 \%$ of the women were overweight and obese (BMI $\geq 25 \mathrm{~kg} / \mathrm{m}^{2}$ ). According to WHO standards, $31.6 \%$ of men and $79.3 \%$ of women $8.6 \%$ of men and $20.3 \%$ of women had high waist circumference and waist/hip ratio values respectively.

Additionally, anthropometric indices, like neck circumferences $(\mathrm{NC})$, other than waist circumferences can be used in determining body fat distribution. NC, as an index of upper-body subcutaneous adipose tissue distribution and reliable, simple, quick method for assessment of overweight and obesity ${ }^{[1,5]}$ However, a standard doesn't exist for neck circumference. Jean Vague was the first researcher to use a neck skinfold to assess upper-body fat distribution. ${ }^{[24]}$ The cut off of level is the NC determined by Liubov and et al ${ }^{[5]}$ and $\mathrm{NC} \geq 37 \mathrm{~cm}$ for men and $\geq 34 \mathrm{~cm}$ for women were the best cut off levels for determining the subject with BMI $\geq 25 \mathrm{~kg} / \mathrm{m}^{2}$.

In present study, the mean $\mathrm{NC}$ of the men and women were $40.27 \pm 3.41 \mathrm{~cm}, 33.43 \pm 3.17 \mathrm{~cm}$ respectively. The $85.1 \%$ of men and $38.8 \%$ of women had NC $\geq 37 \mathrm{~cm}$ and $\geq 34 \mathrm{~cm}$ respectively. In gender, neck circumference correlated positively with body weight, waist circumferences, hip circumferences, waist/ hip ratio and BMI $(\mathrm{p}<0.05)$.

Simpson concluded that lean tissue is a substantial contributor to neck circumference in men. In women, an increased neck circumference appears to be more likely to be associated with a disproportionate increase in fat, despite the tendency of women to accumulate fat more peripherally, as compared with men. ${ }^{[9]}$

There is a strong positive correlation of $\mathrm{NC}$ with BMI and WC in both male and female subjects. Several studies have examined the association of conventional anthropometric measures of obesity with NC. ${ }^{[25,26]}$ 
Neck circumference is a valid marker for identifying obese individuals and correlated well with other anthropometric measurements. Neck circumference has also been shown to correlate positively with insulin resistance and biochemical components of the metabolic syndrome. ${ }^{[27,28,29]}$

Neck circumference was correlated with visieral adipose tissue (VAT) $[\mathrm{r}=0.63 \mathrm{men}$ ); $\mathrm{r}=0.74$ (women); $P<0.001]$ and BMI $[\mathrm{r}=0.79$ (men); $\mathrm{r}=0.80$ (women); $P<0.001]$. After further adjustment for VAT, neck circumference was positively associated with systolic blood pressure, diastolic blood pressure in men only, triglycerides, fasting plasma glucose in women only, insulin, proinsulin, and homeostasis model assessment of insulin resistance and was inversely associated with high-density lipoprotein (all $P$ values $<0.01$ ). ${ }^{[8]}$

In the other study, there was a significant association between changes in NC and changes in body mass index (men, $r=0.67$; women, $r=0.69$; each, $\mathrm{P}<0.0001$ ), waist circumference (men, $\mathrm{r}=0.69$; women, $r=0.56$; each, $\mathrm{P}<0.0001$ ), waist-to-hip ratio (men, $\mathrm{r}=0.27$; women, $r=0.33$; each, $\mathrm{P}<0.0001$ ), total cholesterol (men, $\mathrm{r}=0.68$; women, $\mathrm{r}=0.64$; each, $\mathrm{P}<0.0001)$, low density lipoprotein cholesterol (men, $\mathrm{r}=0.58$; women, $\mathrm{r}=0.59$; each, $\mathrm{P}<0.0001$ ), triglyceride (men, $\mathrm{r}=0.48$; women, $r=0.44$; each, $\mathrm{P}<0.0001$ ), glucose (men, $\mathrm{r}=0.51$; women, $\mathrm{r}=0.44$; each, $\mathrm{P}<0.0001$ ) and uric acid (men, $\mathrm{r}=0.42$; women, $r=0.47$; each, $\mathrm{P}<0.0001)$ levels. The relative changes in $\mathrm{NC}$ contributed to independent significant changes in total cholesterol ( $8 \%$ for men and $1 \%$ for women), low density lipoprotein cholesterol $(1 \%$ for men and $1 \%$ for women) and triglycerides (23\% for men); it did not significantly contribute to changes in high density lipoprotein cholesterol, glucose or uric acid levels. ${ }^{[0]}$

Neck circumference, as an index for upperbody obesity index has been evaluated in relation to cardiovascular risk factors, insulin resistance and biochemical components of metabolic syndrome. [30,31,32,33] Furthermore, the free fatty acid release from upper body subcutaneous fat was found to be larger than from lower-body subcutaneous fat. NC is also related to cardiovascular risk factors in severely obese men and women. It seems, therefore, that with an increase in NC, the likelihood of risk factors for cardiovascular disease also increases. ${ }^{[5]}$

The participants with high NC were more likely to have hypertension, cardiovascular diseases and diabetes mellitus. The participants with high $\mathrm{NC}$ were more likely to have hypertension $(13,8 \%)$, cardiovascular diseases (2.1\%) and diabetes mellitus (4.2\%) (data not shown)

In the population-based evaluation among middle-aged and elderly Turkish adults, NC contributes to MetS likelihood beyond waist circumference and the MetS components. ${ }^{[28]}$ In the community diabetic population based study, NC is related with BMI, waist circumference and metabolic syndrome (MS) in Chinese subjects with type 2 diabetes. ${ }^{[34]}$

\section{Conclusion}

At the end of this study, in both gender there was a significant correlation between neck circumferences and other some anthropometric measurements. So, it may use as a simple screening measure to identify overweight and obese people, especially for clinical practices and epidemiological survey.

\section{References}

1. Hatipoğlu N,Mazıcıŏlu M,Kurtoğlu, Kendirci M.Neck circumference: an additional tool of screening overweight and obesity in chilhood.Eur J Pediatr 2010,169:733-739.

2. Kissebach AH,Vydelinqum N,Murray R,Evans DJ,Hartz AJ.Relation of bodyfat distrubition to metabolic complications of obesity:influence of body fat distrubition.J Clin Endocrinol Metab.1988;67:760-7.

3. Peiris AN, Struve MF, Mueller RA, Lee MB, Kissebah AH.Glucose metabolism in obesity: influence of body fat distribution.J Clin Endocrinol Metab. 1988;67: $760-7$.

4.http://www.emaxhealth.com/1506/neckcircumference-most-reliable-alternative-bmichildhood-obesity.

5.Liubov (Louba) Ben-Noun, Ezra Sohar, Arie Laor. Neck circumference as a simple screening measure for identifying overweight and obese patients. Obesity Research 2001,9 (8):470-477.

6.Liubov Ben-Noun,Arie Laor. $<$ Relationship between changes in NC and change blood pressure.Am J of Hypertention,2004;17(5):409-414.

7. Jing-ya Zhou, Hui Ge, Ming-fan Zhuet al Neck circumference as an independent predictive

contributor to cardio-metabolic syndrome, Cardiovascular Diabetology, 2013; 12:76

8.Sarah Rosner Preis, Joseph M. Massaro, Udo Hoffmann, et al. Neck Circumference as a Novel Measure of Cardiometabolic Risk: The Framingham Heart Study, J Clin Endocrinol Metab, 2010; 95(8): 3701-3710. 
9.Laila Simpson,; Sutapa Mukherjee,; Matthew N. Cooper, et.al. Sex Differences in the Association of Regional Fat Distribution with the Severity of Obstructive Sleep Apnea, Sleep,2010,33(4),467-474.

10.Androutsos O, Grammatikaki E, Moschonis $G$, et al. Neck circumference: a useful creening tool of cardiovascular risk in children,Pediatric Obesity,2012;7(3):187-195.

11.WHO. Obesity: preventing and managing the global epidemic. Report of a WHO Consultation. WHO Technical Report Series 894. Geneva: World Health Organization, 2000.

12.Vanessa Zen, Flávio D Fuchs, Marco V Wainstein, et al.Neck circumference and central obesity are independent predictors of coronary artery disease in patients undergoing coronary angiography. Am J Cardiovasc Dis 2012;2(4):323-330.

13.WHO expert consultation waist circumference and waist-hip ratio Geneva,08.11.2008.

14.http://www.who.int/topics/obesity/en/

15.http://www.who.int/whr/2000/en/whr00_en.pdf

16.http://www.who.int/nutrition/publications/ obesity/WHO_TRS_894/en/index.html

17.Haslam DW, James WP. “Obesity”. Lancet 2005, 366 (9492): 1197-209.

18.Caballero B(2007).'The global epidemic of obesity: An overview. Epidemiol Rev 29: 1-5.

19.Haslam D (March 2007). "Obesity: a medical history". Obes Rev 8 Suppl 1: 31-6.

20.Obesity and overweight. World Health Organization. http://www.who.int/mediacentre/factsheets/fs311/en/index. html. Retrieved April 8, 2009.

21.Spidel JC.Flegal KM. Assessing obesity:

Classification and epidemiology.Br.Med.

Bull.1997,53:238-52.

22.Fledal KM,Carrol MD,Kuczmanski RJ,Jhnnson CL.Overweight and obesity in the United States prevelance and trends,1960-1994Int J Obes Relat. Metab.Disord,1998;22:39-47

23. Onat A., Keleş I, Çetinkaya A, et al. Prevalence of Coronary Mortality and Morbidity in the Turkish Adult Risk Factor Study (TEKHARF): 10-year Follow-up Suggests Coronary "Epidemic" Arch Turk Soc Cardiol 2001; 29:8-19

24.Vague J. The degree of masculine differentiation of obesities:a factor determining predisposition to diabetes, atherosclerosis,gout, and uric calculous disease. Am J Clin Nutr 1956,4:20-34.

25.Nafiu OO, Burke C, Lee J, Voepel-Lewis T, Malviya $\mathrm{S}$, Tremper KK. Neck circumference as a screening measure for identifying children with high body mass index. Pediatrics 2010; 126: e306-10.

26.Janosen I, Heymsfield SB, et al. Body mass index and waist circumference independently contribute to the prediction of nonabdominal, abdominal subcutaneous and visceral fat. Am J Clin Nutr 2002; 75:683-8.

27.Ben-Noun, L., Sohar, E. \& Laor, A. (2001) Neck circumference as a simple screening measure for identifying overweight and obese patients. Obesity Research, 9, 470-477.

28. Laakso M, Matilainen V, Keinänen-Kiukaanniemi S.Association of neck circumference with insulin resistance-related factors.Int J Obes Relat Metab Disord 2002, 26(6):873-5.

29. Onat, A., Hergenc, , G., Yuksel, H. et al. (2009) Neck circumference as a measure of central obesity: associations with metabolic syndrome and obstructive sleep apnea syndrome beyond waist circumference. Clinical Nutrition, 28, 46-51

30. Sjo "stro "m CD, Hakangard AC, Lissner L, Sjo" stro"m L.Body compartment and subcutaneous adipose tissue distribution-risk factor patterns in obese subjects. Obesity Research 1995, 3: 9-22.

31. Ben-Noun LL, Laor A. Relationship between changes in neck circumference and cardiovascular risk factors. Exp Clin Cardiol 2006, 11:14-20.

32. Liubov(Louba) Ben-Noun,Arie Laor.Relationship of neck circumference to cardiovascular risk factors. Obesity Research 2003,11: 226-231.

33. Onat A,Hergenç G,Yüksel H,Can G,Ayhan E, Kaya Z, Dursunoğlu D.Neck circumference as a measure of central obesity:Associations with metabolic syndrome and obstructive sleep apnea syndrome beyond waist circumference, Clin Nutrition.2009,28(1):46-51.

34.Guang-ran Yang, Shen-yuan Yuan, Han-jing Fu, et. al. Neck circumference positively related with central obesity, overweight, and metabolic syndrome in chinese subjects with type 2 diabetes: Beijing Community Diabetes Study. Diabetes Care, 2010, 33 (11): 2465-2467. 